\title{
The Novel "Zuleikha Opens Her Eyes" by G. Yakhina: the Conflict of Receptions in the Context of the Regional, Russian and World Literature (on the Problem of National and Cultural Identity)
}

\author{
Valentina V. Borisova* \\ Bashkir State Pedagogical University \\ named after M. Akmulla \\ $3 a$ Oktyabrskoy Revolyutsii Str., Ufa, 450000, Russia
}

Received 10.01.2017, received in revised form 10.03.2017, accepted 28.04.2017

The article deals with the issue of national and cultural identity in the modern novel "Zuleikha Opens Her Eyes” by G. Yakhina which determined the conflict of receptions in the context of regional, Russian and world literature. It shows that the perception of the novel in the situation of intercultural artistic communication reflects the state of the Russian literary-critical consciousness, not identifying the unity of the internal national and cultural contexts of the work with the external, ones as well as historical, literary, typological and intertextual contexts.

Keywords: Guzel Yakhina, the novel "Zuleikha Opens Her Eyes", the conflict of reception, context, regional literature, Russian and world classical tradition.

DOI: 10.17516/1997-1370-0073.

Research area: philology.

\section{Introduction}

into the Research Problem

The work by G. Yakhina has received quite a wide range of reception from readers and critics, which allows to assess it from the historical-functional and comparative points of view. There is a variety of articles in metropolitan and regional journals and newspapers ("Voprosy Literatury", "Novy Mir", "Oktyabr", "Znamya", "Sibirskie Ogni", "Kazan", "Belskie prostory", "Literaturnaya Gazeta", "Knizhnoe Obozrenie", etc.), but there is no unity in its assessment, though it was honoured with prestige literature awards of 2015-2016 ("The Book of the Year", "The Great Book", "Yasnaya Polyana", etc.). It is more likely that there are "scissors" and contradictions that reveal the conflict of receptions of the much talked about book in the context of regional, Russian and world literature.

\section{Problem Statement}

It seems that the discordant criticism of the novel "Zuleikha Opens Her Eyes" in this case is connected with the problem of actualizing the

C) Siberian Federal University. All rights reserved

* Corresponding author E-mail address: borisova@ufacom.ru 
ideas of the national identity that characterizes the domestic literature of the turn of the $20^{\text {th }}-21^{\text {st }}$ centuries (Kovtun, 2015: 87), which in turn is due to modern processes of interethnic, intercultural communication (Polyakova, 2012: 49). In the work of G. Yakhina, it is predetermined both by the peculiarities of the inner novel context, and by the junction of external, in this case historicalliterary, typological and intertextual contexts of perception and interpretation.

\section{Regional (ethno-cultural) Context of the Novel}

In this case, it is the Tatar and Muslim context, simultaneously receptive and immanent in relation to the work of G. Yakhina. Its first part depicts the life of the protagonist in the small village of Yulbash near Kazan, reproduces the traditional Tatar house-building of the 1930s, the time of collectivization "from the inside". Many critics first of all paid attention to this aspect of the novel.

Thus, Perm literary scholars Marina and Vladimir Abashevs rightly saw in the history of the deceased and exiled Tatar peasant woman in Siberia the reflection of the Soviet history in the national version: "The Tatar world appears moderately exotic, absolutely convincing, yet unobtrusive and absolutely accessible" (Abasheva, Abashev, 2016: 178).

In addition to realias, the national identity has embodied in the language: the text contains generously scattered Tatar words and expressions, included in the dictionary attached to the novel and reflecting, apparently, the communicative strategy of the author who wrote her work primarily for the Russian reader. Although it remains completely Russian-language, as the translator from Turkic languages Alfiya Karimova notes, "the novel is close to the Tatar soul, the Tatar worldview" (Yakhina, 2016: 156). The naturalness of its expression is confirmed by the confession of the writer herself: "There was no need to invent anything. I just wrote about what I knew and felt well" (Yakhina, 2016: 157).

At the same time, she does not consider herself neither a Russian nor a Tatar author, emphasizing her regional affiliation to Kazan, the Eurasian city, in which various national and cultural principles have interwoven organically: "I grew up on the verses of Pushkin and Tukai, I spoke two languages. I would like to be called a Kazan writer" (Pobeditel'nitsa..., 2015).

It is noteworthy, however, that G. Yakhina in this case nevertheless identifies herself in terms of language coordinates of both Russian and Tatar literatures, not accidentally mentioning the names of Pushkin and Tukai. According to the American Slavicist Paul Debreczeny, the inner self of the Russian reader was formed by Pushkin (Debreczeny, 1997: 258). The same, according to M.I. Ibragimov, can be said about the Tatar reader, the inner self of which was formed by G. Tukai. "Correlation of one's inner self with the phenomena of literary reality is one of the significant manifestations of national identity" (Ibragimov, 2005: 203).

The kind of two-culturedness of G. Yakina is also conditioned by biographical factors: childhood spent in a Tatar village and good education, already obtained in the Russian language, allowed her to combine in her work the traditions of the Russian classical literature with national ones, to preserve the mental rootedness in the soil of her native culture with a conscious refusal of provincial remoteness and isolation.

This phenomenon of the "two-cultural" writer, when the language of creative works is Russian, and the native language since childhood is non-Russian, in this case, the Tatar, as is well known, was especially typical for Soviet multinational literature. One of the most striking examples is Ch. Aitmatov, who at the time performed that cultural transfer, as a result of which the Kyrgyz culture became the part of the 
Russian world. However, creativity of G. Yakhina is a phenomenon of not so much national, but postnational literature.

In the novel "Zuleikha Opens Her Eyes", the critic noted this feature in the first place. For example, Elena Pogorelaya noting the abundance of Tatar toponyms, ethnonyms, exotic for Russian ears names of many objects, writes: "The author adds large beads of local flair to the strong thread of the narration: the stolen pastila is hidden under the kulmek - a thin undershirt, one has to make a sacrifice to a spirit - Bass Kapka Iyase - at the village outskirts" (Pogorelaya, 2016: 142). But in the opinion of the Moscow critic, because of this the book by G. Yakhina looks "absolutely ethnographic and museum-like" (Pogorelaya, 2016: 142).

V. Pustovaya, who is also very skeptical about the author's appeal to the forms of national identity, following the principles of traditionalism and national identity, believes that "traditional consciousness is depicted quite primitively in the novel, compromising the national and family way" (Pustovaya, 2016: 129), although and it is important to emphasize, the carrier of this consciousness is the main character. In our opinion, the author consciously uses her "optics", focusing on the image of Zuleikha's inner evolution, the protagonist's transition from the initial physiological experiences of hunger, cold, fatigue to a new, spiritual state.

Paradoxically, the assessment of the opponents from the capital coincided in this case with sharp reviews of regional writers who matched the contemporary novel by Guzel Yakhina, in which the deceased Tatar peasant woman engaged herself with the Russian man, the murderer of her husband, against the tragic novel "Zuleikha" by Gayaz Iskhaki (1907-1912), in which, on the contrary, the protagonist taken away from her children, her husband, native land, forcibly married to a Russian drunkard, kills him, spends twenty years in penal servitude, but does not abandon her faith.

Demanding national apologia, Ufa critic Raif Amirov "caught" the writer in misunderstanding of "Tatar words and, in general, in lack of understanding of the Tatar culture. The author needs to work hard in this direction. Yakhina cannot be put on a par with the great Tatar writers. People will always read them, which is unlikely to be said about her" (Gromkii debiut..., 2016: 170). Risal Mukhametshin, a Kazan critic, was even more aggressive: "There is no Tatar spirit in the work. The author does not understand and does not feel neither the Tatar life, the Tatar traditions, nor Tatarism as such" (Mukhametshin, 2016). Responding to such accusations, the writer remarked: "I could not relate the novel to the Tatar literature. I am interested in the clash of cultures" (Est' li natsional'naia..., 2015: 6).

In other words, for the Tatar Russianlanguage literature the novel about Zuleikha did not become "friendly" (although a year later its translation into Tatar was presented in Kazan). Here there is a problem of the frontier, identification of the national tradition in the situation of intercultural artistic communication.

Let us also give our opinion that it is not only an arguably perceived national flair of the work that is evident: the worldview of the protagonist is distinguished by the dual belief, the coexistence of pagan ideas about the world and the Muslim faith. For example, Zuleikha brings refreshments to the spirits of the cemetery and simultaneously turns to Allah. Unfortunately, the religiousmythological meaning of the work by G. Yakhina remained almost unnoticed by critics, with few exceptions.

\section{The Context of the Russian Classical Literature}

It acts as the main criterion for evaluating the novel "Zuleikha Opens Her Eyes", although 
its reception in this very context is quite ambiguous. Tolerant Perm critics Marina and Vladimir Abashevs saw it as "the subject of collectivization and camps developed in the books by V. Tendryakov, V. Belov, A. Solzhenitsyn and V. Shalamov" and attributed it to modern camp prose, along with Zakhar Prilepin"s novel "Abode". They also noted the connection with Russian women's prose in the novel, stressing that "Yakhina caught the nerve of women's prose precisely in its modern stage typical for the last decade" (Abasheva, Abashev, 2016: 179).

The writer herself also does not hide the conscious "allusions" to Soviet literature. For her it is primarily the works of M.A. Sholokhov, as well as A. Dovzhenko's film "The Earth", an unfinished film by S. Eisenstein "Bezhin's Meadow"). "It's probably natural: we grew up on the works by Sholokhov, Platonov, Shukshin", she says (Yakhina, 2016).

The presence of classical reminiscences in this novel is also outlined by E. Pogorelaya in the journal "Voprosy Literatury", including it in the context of the Russian literature of the $20^{\text {th }}$ century, and noting, for example, similarity of Guzel Yakhina's prose with the prose by Alexei Ivanov, Dina Rubina and Elena Chizhova. In her opinion, in the novel about Zuleikha, "the reminiscential fabric of modernity is stretched on the solid frame of memoirs, recollections and research firmly embedded in the foundation of Babel's "Konarmiya" and Sholokhov's "Virgin Soil Upturned" (Pogorelaya, 2016: 141).

But this recognizable context, despite skillful reminiscences, immediately caused a reproach in the secondary nature of the images and motives: "The former Baltic sailor, later Leningrad top-quality worker Denisov was sent to the village to organize collective farms. And it is here where I want to correct the author: it's Davydov, Sholokhov's Semyon Davydov. Only not a full-blooded image, not even a pale shadow, but a dry outline of it, a skeleton" (Belyakov, 2015: 227). Although the absolute majority of readers have appreciated the images of the novel as full-blooded and vivid.

Therefore, as an intermediate conclusion, let us note the obvious conflict of receptions: on the one hand, although with significant provisions, a number of critics evaluate the work by $G$. Yakhina as a Russian novel of the $21^{\text {st }}$ century, as a novel both classic and innovative, which allows to attribute it to neo-traditionalism in the modern Russian literature.

At the same time, at the Moscow book fairs and festivals, Guzel Yakhina "was quickly put in the position of a conductor of the Tatar culture and burdened with the national question", and the critic M. Savelyeva in this connection spoke about the tasks of "new national literatures" designed to return post-traditional society to adoption of the national in itself" (Savelyeva, 2015: 135), apparently believing that for the Russian literature itself it is no longer relevant. "A new ethnic literature comes to replace Grant Matevosyan, Nodar Dumbadze, Vasil Bykov and Guzel Yahina can become its flagship" (Est' li natsional'naia..., 2015: 7).

Thus, the views "from the outside" and "from the inside" on the novel by G. Yakhina did not coincide: in the capital it was appreciated as a phenomenon of the all-Russian novel, in Kazan and Ufa it was given almost a hostile reception: the national was perceived in the likelihood coordinates, and not artistic truth, without taking into account the artistic conventionality of depicting the historical reality.

\section{The Context}

\section{of the World Literature}

In our opinion, G. Yakhina's novel is quite organically perceived in the context of the world literature. Comparing it with domestic village and camp prose, one should not forget the traditions 
of the world literature. "I think that the graduate of the foreign languages department of Kazan University came out not only from the camp robes of A.I. Solzhenitsyn, but also from the more civilized clothes of European and American literatures" (Gromkii debiut..., 2016: 170-171).

Against this background, the innovative nature of the novel "Zuleikha Opens Her Eyes" is particularly noticeable. G. Yakhina shows the tragedy of dekulakization and forced collectivization in Russia as a shock for the centuries-old foundations of human life. And here she follows not only the traditions of the "Quiet Don", as P. Basinsky believes, but also the ideas of "Robinson Crusoe" by D. Defoe: "The depiction of the life of the dispossessed kulak settlers on the Angara entails the features of utopia, Robinsonade" (Abasheva, Abashev, 2016: 178), in general, in our opinion, the world story of survival.

The novel describes in detail the challenges that the immigrants face in a remote taiga. They dig their first dugout shelter like Robinsons with their hands, they make spoons from river shells. These are real details and realias of everyday life of the people who were "evicted to wild lifeless places and left alone with death, whether they were in the Kazakh steppe, the permafrost of the North or the taiga" (Pobeditel'nitsa..., 2015).

A parallel with the novel-epic "Gone with the Wind" by M. Mitchell is also observed. This was also first noticed by Marina and Vladimir Abashevs, calling Zuleikha a "Siberian Scarlett" (Abasheva, Abashev, 2015: 182). In addition to a certain typological similarity between the spirit of the protagonists, the importance of the metaphorical and symbolic motif of the "wind" can be noted: Zuleikha at first was nearly "carried away" by the wind in her native urman, and then the Siberian wind, the wind of history, which, like Scarlett O'Hara, she survived through.
As the Perm critics (almost only them) remarked, one of the most important artistic resources in the novel by G. Yakhina, is myth. In their opinion, "the mythological consciousness is most fully reproduced at the beginning of the novel, when young Zuleikha is in the bosom of her native culture" (Abasheva, Abashev, 2016: 179). Then the protagonist "goes away from paganism, from the clan collective unconscious, reminiscent of itself in dreams about Upyrikha", becoming a person with an awakened consciousness.

"But the novel as a whole is formed by quite different mythological images and plots. The names of Yuzuf and Zuleikha remind of a wellknown Biblical-Koranic plot". In our opinion, this is not a random author's marking. "The very birth of Yuzuf is the birth of a mythological hero" (Abasheva, Abashev, 2016: 180), a future prophet.

Of course, there is a famous eastern legend about Joseph (Yusuf) and Zuleikha, who, having entered the Torah, the Bible and the Koran, caused many poetic imitations and transcriptions, including the famous poem "Kyssa-i Yusuf" (The Story of Joseph) by Kul Gali. Despite the strong transformation, its main motifs and images were preserved in the novel by G. Yakhina. First of all, this is Zuleikha's love for Yuzuf, even though maternal, but also equal to the feeling described by the ancient authors: "her soul sang", "her heart was beating with one name: Yuzuf" (Yakhina, 2017: 285).

Another legend significant in the structure of the novel is the Sufi legend of the Simurgh bird narrated by Zuleikha to her son. Simurgh is translated from Persian as "thirty birds". In the Tatar version, this name sounds like Semrug. It echoes the name of the settlement of the special settlers of Semruk, exposing the deep ideological essence of the novel, the fate of thirty settlers. Like the birds from the ancient eastern legend, they crossed the seven valleys - the Valley of Searches, Love, Cognition, Indifference, Unity, 
Confusion and Renunciation - and when they got to the desired place looking around, they understood: Simurgh is themselves one by one and taken together. And Zuleikha "opening her eyes" has also transformed: from a "weakling", as her mother-in-law Upyrikha called her, she turns into a strong bird Semrug, so strong that she lets her son from under her wing into the big world.

\section{Conclusion}

Therefore, we can talk about the rooting of the novel by G. Yakhina in the soil of the Tatar,
Russian and world literature, as well as folklore and myth. It seems that this was the reason for the great success among readers, despite the discordant criticism and the conflictuality of the receptions considered. However, they rather reflect the state of the contemporary Russian literary-critical consciousness, which does not identify the unity of the internal nationalcultural contexts inherent in the creative work with the external historical-literary, typological and intertextual contexts. But these are already problems of our criticism and literary studies, and not of readers and the author.

\section{References}

Abasheva, M. and Abashev, V. (2016). Kniga kak symptom. Kak sdelan roman Guzeli Yakhinoi "Zuleikha otkryvaet glaza" [A book as a symptom. How the novel "Zuleikha Opens Her Eyes" by Guzel Yakhina is made], In Novyi mir [New World], 5, 177-182.

Belyakov, S. (2015). Sovetskaia skazka na fone GULAGa [Soviet fairy tale on the background of GULAG], In Ural, 8, 226-230.

Debreczeny, P. (1997). Social Functions of Literature: Alexander Pushkin and Russian Culture. Stanford, California. 300 p.

Est' li natsional'naia literature v Rossii [Is there national literature in Russia?] (2015), In Knizhnoe obozrenie [Book Overview], 16-17, line 6.

Gromkii debiut. Obsuzhdenie romana G. Yakhinoi "Zuleikha otkryvaet glaza" [The discussion of the novel "Zuleikha Opens Her Eyes" by Guzel Yakhina] (2016), In Belskie prostory [Great open spaces], 6, 166-171.

Ibragimov, M.I. (2005). "Chitatel"” v komparativistike: problem i aspekty izucheniia [The reader in comparative studies: problems and aspects of study], In Russkaia i sopostavitel'naia filologiia [Russian and Comparative Philology], Kazan, 200-205.

Kovtun, N.V. (2015). Sovremennyi russkii traditsionalizm: itogi i perspektivy. Mezhdunarodnyi nauchnyi seminar "Russkii traditsionalizm: istoriia, ideologiia, poetika, literaturnaia refleksiia" [Modern Russian traditionalism: results and perspectives. International Scientific Workshop "Russian traditionalism: history, ideology, poetics, literary reflection"], In Filologicheskii klass [Philology Class], 4, 87-90.

Novaia etnicheskaia literatura [New ethnic literature]. (2015). In Knizhnoe obozrenie [Book Overview], 11, line 7.

Pobeditel'nitsa "Bolshoi knigi" Guzel Yakhina: "Ia by khotela, chtoby menia nazyvali kazanskoi pisatel'nitsei" [The winner of the "Big Book" prize Guzel Yakhina: "I would like to be called a Kazan writer”]. (2015). In Vecherniaia Kazan' [Evening Kazan']. Available at: http://www.evening-kazan.ru/ articles/pobeditelnica-bolshoy-knigi-guzel-yahina-ya-by-hotela-chtoby-menya-nazyvali-kazanskoypisatelnicey.html (accessed on 10.11.2016).

$$
-659-
$$


Pogorelaya, E.A. (2016). Chelovecheskoe, slishkom chelovecheskoe? [Human, too human?], In Voprosy literatury [Literature Issues], 3, 139-150.

Polyakova, L.V. (2012). Problemnaia situatsiia v sovremennoi literaturovedcheskoi terminologii: "Natsional'naia identichnost" [A problematic situation in modern literary terminology: "National identity"], In Vestnik Tambovskogo universiteta [Tambov University Bulletin], Series: The Humanities, 2 (106), 43-52.

Pustovaya, V.E. (2016). Bolshoi roman s vishenkoi [A big novel with a cherry on the top], In Voprosy literatury [Literature Issues], 3, 125-138.

Savel'eva, M. (2015). Utverzhdenie cherez otritsanie [Affirmation through negation], In Oktyabr [October], 12, 132-136.

Mukhametshin, R. (2016). Tatrskie literatory razoshlis' v otsenke odnoi iz samykh uspeshnykh rossiiskikh knig 2015 goda [Tatar literary critics diverged in assessment of one of the most successful books of 2015]. Available at: https://www.business-gazeta.ru/article/300676 (accessed on 10.11.2016)

Yakhina, G. (2017). Zuleikha otkryvaet glaza [Zuleikha Opens Her Eyes]. Moscow, AST. 508 p.

Yakhina, G. (2016). "Mne nravitsia skladyvat' istorii". Besedu vela A. Karimova [“I like to make stories up". Conversation with A. Karimova], In Voprosy literatury [Literature Issues], 3, 151-159.

\section{Роман Г. Яхиной «Зулейха открывает глаза»: \\ конфликт рецепций в контексте региональной, русской и мировой литературы \\ (к проблеме национально-культурной \\ идентичности)}

\section{В.В. Борисова}

Башкирский государственный педагогический университет им. М. Акмулль Россия, 450000, Уфа, ул. Октябрьской револючии, 3/a

\footnotetext{
В статье рассматривается проблема национально-культурной идентичности современного романа Г. Яхиной «Зулейха открывает глаза», которая предопределила конфликт рецепџий в контексте региональной, русской и мировой литературы; показывается, что его восприятие в ситуации межкультурной художественной коммуникации отражает состояние российского литературно-критического сознания, не идентифицирующего единство внутренних национально-культурных контекстов произведения с внешними, историко-литературными, типологическими и интертекстуальными контекстами.
}

Ключевые слова: Гузель Яхина, роман «Зулейха открывает глаза», рецептивный конфликт, контекст, региональная литература, русская и мировая классическая традиция.

Научная спеииальность: 10.00.00 - филологические науки. 